\title{
Work Related Injury among Welders Working in Metal Workshops of Dharan Municipality, Nepal
}

\author{
Anup Ghimire, ${ }^{1}$ Shyam Sundar Budhathoki, ${ }^{1}$ Surya Raj Niraula, ${ }^{1}$ Abha Shrestha, ${ }^{2}$ Paras K Pokharel ${ }^{1}$ \\ 1School of Public Health \& Community Medicine, B P Koirala Institute of Health Sciences, Dharan, Nepal. \\ ${ }^{2}$ Department of Community Programs, Dhulikhel Hospital-Kathmandu University Hospital, Kavre, Nepal.
}

\begin{abstract}
Background: Injuries are a problem worldwide in all occupations. Welders are exposed to many hazards at work resulting in a variety of health problems including injuries at work. This study was conducted to find out the prevalence and factors associated with injuries among welders in Dharan city of eastern Nepal.

Methods: A cross sectional study was conducted among 86 welders in Dharan city. Occurrence of injury in past 2 weeks and past 12 months were recorded. Data regarding sociodemographic along with occupational characteristics was collected using semi structured questionnaire. Data analysis was done using SPSS version 17.

Results: All the welders in this study were male with almost half of the welders under the age of 25 years and about a fifth $(21.1 \%)$ of the welders having received some form of welding training. In the past 12 months, $21.1 \%$ of the welders suffered from work related injuries. More than $95 \%$ welders used at least one personal protective equipment in this study. More injuries were seen among welders with age $\geq 35$ years, working experience $\geq 5$ years, not received training and not using of PPE at work. However, these factors were not found to be statistically significant.

Conclusions: Work related injuries are high among welders of Dharan. Further research is required to explore the relationship between age, literacy, training and use of personal protective equipment with the occurrence of injuries among the welders.

Keywords: Injury; Nepal; welders; work-related injuries.
\end{abstract}

\section{INTRODUCTION}

Globally, injuries are regarded as the under recognized public health problem. ${ }^{1}$ Welders are workers who join and cut metal parts using flame or electric arc and other sources of heat. ${ }^{2}$ Welder are exposed to fumes causing metal fume fever ${ }^{3}$ and to glare and ultraviolet rays causing 'arc eye' or 'flash burn' injuries to the cornea and double vision leading to retinal damage. ${ }^{46}$ Welders report variety of musculoskeletal problems and injuries. ${ }^{5}$ Welding is used in metallic constructions, and demands certain postures for a long time. Risk of injuries due to fire/explosion, radiation, electric shock or materials handling seem inevitable. ${ }^{7}$

Injury was the most common complaint at work among welders in Nepal. ${ }^{5}$ This study was conducted to find out the prevalence of injury among welders and to assess the factors affecting work-related injury among welders in Dharan city of eastern Nepal.

\section{METHODS}

This cross-sectional study was conducted in Dharan city from August 2011 to July 2012. Using the prevalence of $37.7 \%$ injuries among the welders in Benin ${ }^{6}$ and taking $10 \%$ absolute precision, the sample size was calculated to be 91 . We obtained a list of 20 metal workshops (Grill workshops) registered at the Grill Workshops Association (Sanyukta Grill Byabasyi Sangh, Dharan). Preliminary survey revealed 3-4 welders per workshop and we decided to include all 86 welders in these workshops in our study, which was $95.5 \%$ of the required sample size.

We developed a semi-structured questionnaire to collect the data on socio-demographic profile, frequency of injury in past 2 weeks and past 12 months, characteristics of injury and use of personal protective equipment at work. The data was collected using interview method at the workplace of the welders. Welders who were not present at the day of interview were contacted and
DOI: http://dx.doi.org/10.3126/

jnhrc.v16i2.20302
Correspondence: Prof Anup Ghimire, School of Public Health \& Community Medicine B P Koirala Institute of Health Sciences, Dharan, Nepal. Email: anup.ghimire@gmail. com, Phone: +9779842022356 . 
interview was scheduled for another convenient day.

Data was checked for completeness and entered into Microsoft excel at the end of each day. Data analysis was done using the Statistical Package for Social Sciences (SPSS) 17 software. Data was analysed considering 95\% confidence interval and $5 \%$ level of significance.

Ethical approval (Ref: Aca-216/068/069) for this study was taken from the Institutional Review Committee (IRC) of B P Koirala Institute of Health Sciences. Informed consent was taken from the welders before the data collection was done. Data reflecting personal identifications were not collected.

\section{RESULTS}

All the 86 welders identified during the preliminary survey participated in the study. Almost half $(44.2 \%)$ of the welders were between the age of 16 and 25 years of age. Most of them (88.4\%) were literate. Half of the welders were working for 5 years and $2 / 3$ rd of them work for less than 8 hours daily. Only one third of the welders had received basic welding training (Table 1).

\begin{tabular}{|c|c|c|c|}
\hline \multicolumn{2}{|c|}{ Characteristics } & \multirow{2}{*}{$\begin{array}{r}\text { Frequency } \\
38\end{array}$} & \multirow{2}{*}{$\begin{array}{r}\text { Percentage } \\
44.2\end{array}$} \\
\hline \multirow{4}{*}{ Age } & $16-25$ years & & \\
\hline & $26-35$ years & 28 & 32.6 \\
\hline & $36-45$ years & 14 & 16.3 \\
\hline & $>45$ years & 6 & 6.9 \\
\hline \multirow{2}{*}{$\begin{array}{l}\text { Literacy } \\
\text { status }\end{array}$} & Literate & 76 & 88.4 \\
\hline & Illiterate & 10 & 11.6 \\
\hline \multirow{2}{*}{$\begin{array}{l}\text { Working } \\
\text { experience }\end{array}$} & $<5$ years & 43 & 50.0 \\
\hline & $\geq 5$ years & 43 & 50.0 \\
\hline \multirow{2}{*}{$\begin{array}{l}\text { Daily } \\
\text { working } \\
\text { hours }\end{array}$} & $<8$ hours & 56 & 65.1 \\
\hline & $\geq 8$ hours & 30 & 34.9 \\
\hline \multirow{2}{*}{$\begin{array}{l}\text { Basic } \\
\text { Welding } \\
\text { training } \\
\text { received }\end{array}$} & Yes & 26 & 30.2 \\
\hline & No & 60 & 69.8 \\
\hline
\end{tabular}

The prevalence of work related injury in past 2 weeks was $4.7 \%$, while in the past 12 months was $22.1 \%$. Among the injured welders $(n=19)$, about $37 \%$ of them were injured more than once in the past 12 months. Most frequently $(63 \%)$ injured body part was the upper body including the upper arms. Burns was the most common form of injury among the welders (Table 2 ).

\begin{tabular}{|c|c|c|c|}
\hline Variable & & Frequency & Percentage \\
\hline \multirow{2}{*}{$\begin{array}{l}\text { Occurrence } \\
\text { of Injury in } \\
\text { past } 2 \text { weeks } \\
(n=86)\end{array}$} & $\begin{array}{l}\text { Injury } \\
\text { present }\end{array}$ & 4 & 4.7 \\
\hline & $\begin{array}{l}\text { Injury } \\
\text { absent }\end{array}$ & 82 & 95.3 \\
\hline \multirow{2}{*}{$\begin{array}{l}\text { Occurrence } \\
\text { of injury } \\
\text { in past } 12 \\
\text { months } \\
(n=86)\end{array}$} & $\begin{array}{l}\text { Injury } \\
\text { present }\end{array}$ & 19 & 22.1 \\
\hline & $\begin{array}{l}\text { Injury } \\
\text { absent }\end{array}$ & 67 & 79.9 \\
\hline \multirow{2}{*}{$\begin{array}{l}\text { Frequency of } \\
\text { injury }(n=19)\end{array}$} & Once & 12 & 63.2 \\
\hline & $\begin{array}{l}\text { More than } \\
\text { once }\end{array}$ & 7 & 36.8 \\
\hline \multirow{4}{*}{$\begin{array}{l}\text { Location of } \\
\text { injury in the } \\
\text { body }(n=19)^{*}\end{array}$} & Eye & 4 & 21.1 \\
\hline & Face & 4 & 21.1 \\
\hline & $\begin{array}{l}\text { Upper } \\
\text { body }\end{array}$ & 12 & 63.2 \\
\hline & $\begin{array}{l}\text { Lower } \\
\text { body }\end{array}$ & 5 & 26.3 \\
\hline \multirow{3}{*}{$\begin{array}{l}\text { Type of } \\
\text { injury }(n=19)\end{array}$} & Burns & 10 & 52.6 \\
\hline & Cuts & 6 & 31.6 \\
\hline & Both & 3 & 15.8 \\
\hline *Multiple responses & & & \\
\hline
\end{tabular}

Use of at least one personal protective equipment (PPE) at work was seen among $95.5 \%$ of the welders (Not shown in table). Injuries in the past 12 months were seen more among the welders with age $\geq 35$ years, literate, welders who had not received training and welders who did not use PPE at work. However, bivariate analysis showed that none of the socio-demographic as well as work related characteristics was associated with the occurrence of the injuries among the welders (Table 3 ).

\begin{tabular}{|c|c|c|c|c|}
\hline Characteristics & & Presence of injury (\%) & Absence of injury (\%) & OR $(95 \% \mathrm{Cl})$ \\
\hline \multirow{2}{*}{ Age } & $<35$ years & $11(18.03)$ & $50(81.97 \%)$ & 1 \\
\hline & $\geq 35$ years & $8(32.00)$ & 17 (68.00\%) & $2.31(0.73-6.19)$ \\
\hline \multirow{2}{*}{ Literacy status } & Literate & 17 (22.37) & $59(79.63 \%)$ & 1 \\
\hline & Illiterate & $2(20.00)$ & $8(80.00 \%)$ & $0.86(0.16-4.47)$ \\
\hline \multirow{2}{*}{ Working Experience } & $<5$ years & $7(16.28)$ & $36(83.72 \%)$ & 1 \\
\hline & $\geq 5$ years & $12(27.91)$ & 31 (72.09\%) & $1.99(0.69-5.68)$ \\
\hline \multirow{2}{*}{ Daily Working hours } & $<8$ hours & $14(25.00)$ & $42(75.00 \%)$ & 1 \\
\hline & $\geq 8$ hours & $5(16.67)$ & $25(83.33 \%)$ & $0.60(0.19-1.86)$ \\
\hline
\end{tabular}


Work Related Injury among Welders Working in Metal Workshops

\begin{tabular}{|c|c|c|c|c|}
\hline \multirow{2}{*}{ Supervisor present at work } & Yes & $11(22.92)$ & $37(77.08 \%)$ & 1 \\
\hline & No & $8(21.05)$ & $30(78.95 \%)$ & $0.89(0.32-2.51)$ \\
\hline \multirow{2}{*}{$\begin{array}{l}\text { Basic Welding training } \\
\text { received }\end{array}$} & Yes & $4(15.38)$ & $22(84.92 \%)$ & 1 \\
\hline & No & $15(25.00)$ & $45(75.00 \%)$ & $1.83(0.54-6.17)$ \\
\hline \multirow{2}{*}{ Use of PPE at work } & Yes & $18(21.95)$ & 64 (78.05\%) & 1 \\
\hline & No & $1(25.00)$ & $3(75.00 \%)$ & $1.85(0.11-12.09)$ \\
\hline
\end{tabular}

\section{DISCUSSION}

Welding regarded a hazardous profession, ${ }^{7}$ is also common in Nepal. There are limited studies in occupational health in Nepal, ${ }^{8-10}$ and only two studies, ${ }^{5,11}$ are found regarding the health of welders in Nepal. These studies report a wide range of problems among welders in Nepal including arc related problems, metal fume fever related problems, asthma related symptoms, hearing problems, musculoskeletal problems and injuries. ${ }^{5}$ The use of PPE is low among the welders. ${ }^{11}$ This study reports injuries among welders working in a city in eastern Nepal. The main findings of this study include $22 \%$ of the welders reporting injuries in past 12 months, more than half of welders under the age of 35 , high literacy among the welders, one fifth of the welders having some basic training of welding and most welders wearing at least one PPE.

All the welders in this study are male, which is in line with another study ${ }^{11}$ in Nepal and elsewhere. ${ }^{12,13}$ Welding as a profession predominantly undertaken by males globally. The age group of the welders is similar with studies in Nepal and Nigeria, where a major proportion of welders are of younger age. ${ }^{6,11}$ Literacy status among the welders in this study is also similar to other studies. ${ }^{6,11}$

The prevalence of injury $(22.1 \%)$ is slightly lower than the report from other cities of eastern Nepal, ${ }^{14}$ reported as $36.5 \%$. Lower injury among the welders in this study could be due to the presence of welders with welding training, which was absent in another study. Another study covering eastern Nepal, ${ }^{5}$ also reports that none of the welders in that study had received any formal training in welding and the presence of injury as $90 \%$ compared to this study. ${ }^{5}$ Burns are reported as the most common form of injury in this study followed by cuts. The study from Benin, reports cuts as the most common form of injuries followed by burns. ${ }^{6}$ More than $1 / 3^{\text {rd }}$ of the welders in this study who reported having sustained injury in past 12 months, reported injury more than once. This is also reported from India ${ }^{13}$ and Africa. ${ }^{6}$

The use of at least one PPE in this study was high, compared to the finding from eastern Nepal. ${ }^{11}$ Use of PPE was also lower in the study in Benin. ${ }^{6}$ However, further assessment may be needed to explore the use of appropriate PPE recommended for welders in the area. As this study was more focused on the prevalence of injuries, there is a limitation to comment on other health problems as well as the use of recommended PPE. This study was not able to identify, factors associated with the occurrence of injuries among the welders in Dharan as there was no statistical significance observed. This could be due to small sample size of the study. However, injuries are not associated with any factors in another study from eastern Nepal. ${ }^{5} \mathrm{~A}$ robust study with a large sample size may be required to assess the factors associated with injuries among welders.

\section{CONCLUSIONS}

Work related injuries are frequent among the welders in Dharan. Very less number of welders have received basic welding training. Further investigation as to why the welders are still sustaining work related injuries is needed despite the high use of at least one PPE. While work related injuries have some association with age, experience of welders, training and use of PPE, further research may be needed to establish the predictors of work related injuries among the welders.

\section{ACKNOWLEDGEMENTS}

We thank BP Koirala Institute of Health Sciences for supporting the study as well as the colleagues at School of Public Health and Community Medicine, who helped during the conduction of the study. We also thank the welders who participated in this study as well as the officials of Grill workshops Association for their timely coordination and cooperation for this study.

\section{REFERENCES}

1. Sleet DA. Injury prevention and public health. Ital J Public Health. 2010;7(2):3-5. [ Full Text]

2. International Labor Organisation. International Standard Classification of Occupations. Vol. I. 2012. [다ll Text]

3. El-Zein M, Infante-Rivard C, Malo J, Gautrin D. Is metal fume fever a determinant of welding related respiratory symptoms and/or increased bronchial responsiveness? 
A longitudinal study. Occup Env Med. 2005;62:688-94. [Pub Med]

4. Davies KG, Asanga U, Nku CO, Osim EE. Effect of chronic exposure to welding light on Calabar welders. Niger J Physiol Sci. 2007;22(1-2):55-8. [르 Med]

5. Budhathoki SS, Singh SB, Niraula SR, Pokharel PK. Morbidity patterns among the welders of eastern Nepal: a cross-sectional study. Ann Occup Environ Med. 2016;28(1):62. [ [Full Text]

6. Isah EC, Okojie OH. Occupational Health Problems of Welders in Benin City , Nigeria. J Med Biomed Res. 2006;5(1):64-9. [Full Text]

7. Antonini JM. Health Effects of Welding. Crit Rev Toxicol. 2003;33(1):61-103. [Full Text]

8. Joshi SK, Shrestha S, Vaidya S. Occupational Safety and Health Studies in Nepal. Int J Occup Saf Heal. 2011;1:19 26. [Full Text]

9. Bhattarai D, Singh SB, Baral D, Sah RB, Budhathoki SS, Pokharel PK. Work-related injuries among farmers: a cross-sectional study from rural Nepal. J Occup Med Toxicol. Journal of Occupational Medicine and Toxicology; 2016;11:48. [Pub Med]
10. Singh SB, Bhatta N, Jha N, Pokharel PK. Respiratory morbidities of jute mill workers in Nepal. Health Renaiss. 2012;10(3):181-6. [Full Text]

11. Budhathoki SS, Singh SB, Sagtani RA, Niraula SR, Pokharel PK. Awareness of occupational hazards and use of safety measures among welders: a cross-sectional study from eastern Nepal. BMJ Open. 2014;4(6):e004646. [Full Text]

12. Ajayi IA, Adeoye AO, Bekibele CO, Onakpoya OH, Omotoye OJ. Awareness and utilization of protective eye device among welders in a southwestern Nigeria community. Ann Afr Med. 2011;10(4):294-9. [Pub Med]

13. Kumar SG, Dharanipriya A. Prevalence and pattern of occupational injuries at workplace among welders in coastal south India. Indian J Occup Environ Med. 2014;18(3):135-9. [ [Pub Med]

14. Ghimire A, Raj Niraula S, Badhur Singh S, Uprety S, Pokharal PK. Magnitude and associated risk factors of injuries among welders working in grill workshops. In: Injury Prevention. 2012. p. A157-8. [ull Text] 